\title{
Vernacular Architectural Preservation of Material and Spiritual Interconnected Cultural Heritage
}

* B.A. ALMIRA KHAFIZOVA

Department of Architecture, Girne American University, Turkey

E mail: halmirah@hotmail.com

\begin{tabular}{|l|}
\hline A R T I C L E I N F O: \\
\hline Article history: \\
Received 15 July 2018 \\
Accepted 23 September 2018 \\
Available online 13 October \\
2018 \\
\hline \\
Keywords: \\
Vernacular \\
Architecture; \\
Arkaim; \\
Chum; \\
Tipi. \\
\end{tabular}

This work is licensed under a Creative Commons Attribution - NonCommercial - NoDerivs 4.0. "CC-BY-NC-ND"

\begin{abstract}
A B S T R A C T
Vernacular architecture presents sustainable minimum-impact structures harmonized with their context and inhabitants. Heritage preserved tangible and intangible in material forms, encrypted spiritual believes of humanity's life in dwellings' organization unveiling the details of our ancestors' life and world cultures' connectivity. Instigated by modern-world urbanization, sustainability and cultural diversity issues, the study is researching on cultures connectivity, corresponding to the scale and context of the global cityscape and attempting to synthesize vernacular heritage. The objective of this research is to study indigenous human congruent architectural examples and their relationship with intangible aspects of habitat. This paper will be adapting a qualitative method, by which it aims to study and observe various examples so as to analyze interconnections of Siberian Chums and Native-American Tipi, their design driving forces, settlement of the 2 nd century BC-Arkaim and Japanese traditional architecture.
\end{abstract}

JOURNAL OF CONTEMPORARY URBAN AFFAIRS (2018), 2(3), 10-19.

https://doi.org/10.25034/ijcua.2018.4714

www.ijcua.com

Copyright @ 2018 Journal Of Contemporary Urban Affairs. All rights reserved.

\section{Introduction}

Vernacular architecture bears climate-efficient regional and time proven sustainable systems, the analysis of which can benefit locally oriented modern architecture. Through the study of various examples, one can notice the firm presence of spiritual aspects, religious or pagan believes as driving forces of dwellings' planning. Space will always remain to be very influential to the quality of human life that is based on intangible psychological aspects and habitual traditions. Importance of vernacular architecture's preservation is indisputable, it absorbs to reflect culture and traditions performing as a living historical evidence. Thus analyzing extant vernacular architectural forms and venturing into their inner space organizations this study seeks to identify the unifying principle.

The case of Siberians and Native American inhabitants' architecture similarities is not a coincidence, it is another proof of cultures' links on a par with language analogies proposed by Edward Vajda and detailed DNA analysis held by the Centre for GeoGenetics. As two

\footnotetext{
*Corresponding Author:

Department of Architecture, Girne American University,

Turkey

E-mail address: almira.khafizou@std.gau.edu.tr
} 
distantly evolving communities, Siberian including Nenets, Evenks, Navkhs, Yuits, Kereks and Native Americans or so-called Indians have same believes, shamanic background and therefore architectural analogies shown in Chums and Tipis.

Centralization of fire, noticed in Japanese architecture and so common for Zoroastrian architecture is seen in both of previously noted vernacular dwellings' examples as well as in another case of research, the Bronze Age settlement of Arkaim inhabited by Agniworshipers. Studied in light of cultural connectivity through the intangible background of spaces design by first architects, its religious aspect may link it with present-day differentiated cultures and arise more research possibilities.

\section{Siberian Chum - the life center of Nenets people}

Siberia region of Russia has exceptional architectural treasures, carefully transferred to the modern world by the indigenous population of this region. The example of chums is referred to Middle Siberia inhabited by Nenets tribes, also noticed in the cultures of Hasova, Samoeds, Evenks, Navkhs and Uraks. Yamal peninsula, the place where Nenet people abide, is not an exception for the impetus of infrastructure in the $21^{\text {st }}$ century.

Local research conducted by Boyarsky and Stolyarov (2000) shows that Yaman peninsula, and Vaigach Island in particular, was preserved and guarded by locals in the past because of its significance and sacred meaning. Moreover, as R. Jones, a member of S. Borrough's expedition held in 1556, wrote: "wild Samoyeds live there, not allowing Russians to land". (Boyarsky, Stolyarov, 2000, p. 30) However, inducing an economic interest nowadays, the region inhabited by Nenets is under the process of new development. With the construction of Obskaya-Bovanenkovo railway line, which is the northernmost in the world, Yamal Project has already impacted the local land ecosystem and the nomadic pace of Samoyedic life that was followed for centuries by disrupting their migration routes. Chance (1995) and Andreeva point on the problematic situation in the Russian North, saying that nowadays it is experiencing most dramatic environmental devastation that directs to the social disintegration. (N. A. Chance, E. N. Andreeva, 1995).

The harsh climate with long winters and seasonal winds, severe waterlogging, and isolation forced ethnic group to adhere to their centuries' nomadic routine solely dependent on hunting and deer keeping. Same as centuries ago, today Chum remains the center of Nenets' lives, both habitual and sacred. However, this example shows that a vernacular dwelling preserves much more than a material architectural form.

Detailed information was provided by the expedition of D. Andersons, in collaboration with the archaeological field research team of Dr. Viktor Vetrov of the Irktusk State Pedagogical University and Baikal- Hokkaido Archaeology Project (BAP) and then documented by Andersons. The author states that Evenk's cone-shaped dwelling is an example of "how vernacular architecture reflected social structure" $(2,2006)$. An influential work done by Shirokogoroff (1929) unveils details of the indigenous pace of life and the meaning behind its details, providing "an early authoritative schematic of the structure of a conical lodge with its distinctive pattern of names, which in turn implied certain roles to men, women and to guests". (1929, pp. 255-256).

\subsection{Spiritual understanding of the world behind the spatial organizations of the dwelling.}

Same as in the previous century, modern chums bear the original vernacular exterior and interior spatial organization that have carried traditions, language and religion by the definite interdependence between form and function. Similarly as for inhabitants of North America or Canadian Plains, most aspects of Nenets' life are interlinked with shamanism and this belief is shared among most of the aboriginal cultures of Siberia.

In shamanism, the world differentiated into three partials: the sky, the land, and the underground are believed to be inhabited by human souls as well as by many other spirits, gods, protectors, and helpers that only shaman can reach to. For aboriginals of Siberia their self-eidolon was not differentiated from animals. It is important to mention that images of the world tree, the bear and the bird play a significant role in their life and folklore. (Mchedlov, et al., 2002)

Despite forced Christianization, Siberian aboriginals preserved their religious and cultural identity, animism, totemism and shamanism, thanks to the successive mode of life and continuous direct dependence from nature. Chum, the resultant of nomadic Nenets' life has always remained habitual and sacred central element. The dismountable dwelling's spatial arrangement goes in accordance with 
shamanic order, hierarchy of the clan and gives meaning to all the dwellings' elements.

Reindeers are the source of food, clothing and building materials, all necessities for Indigenous Siberians, Nenets in particular (Lissner, 1961). Constructed not without materials provided by deer, chum's conical structure with an inlet for the smoke (Sona) is covered by the sewed skins in the winter or with boiled bark, canvas and burlap in the summer. Dwelling's frame consists of approximately 40-50 sloping poles (Golovnev, 1995).

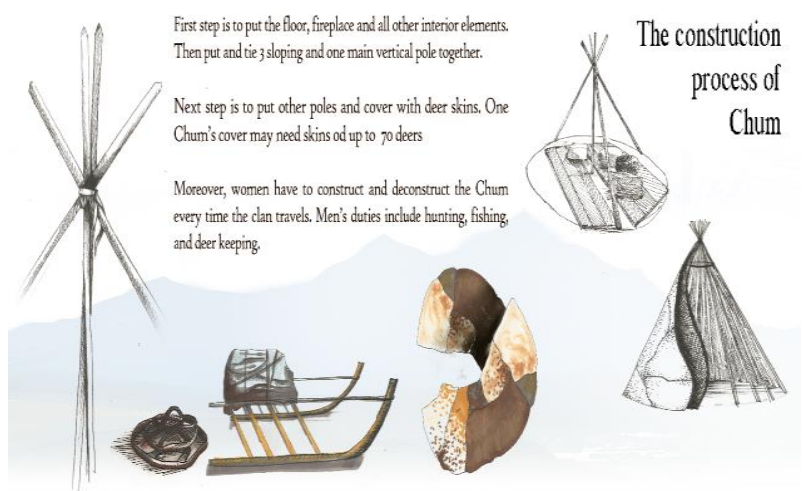

Figure 1. Construction process (Developed by Author).

The location of the chum is decided by man and the first act, placement of the metal fire sheet [Tumu] on the ground, by woman. Thus the hearth becomes the central, first and most significant element of the house. Golovnev wrote that "Perhaps in this first movement, the idea of the 'hole' to the lower world coverage and the symbolism of the primary designation of the center and the history of the chum itself which was originally a "bonfire closed from the wind", are combined." (1995, p. 212).

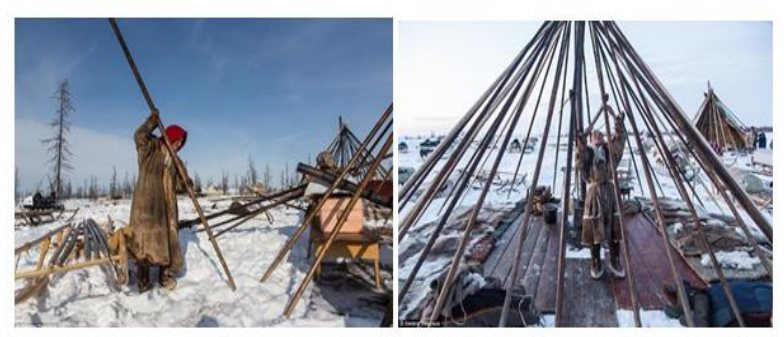

Figure 2. Woman installs 'simzi'. (Dmitry Figure 3. Installment of suspended fumace Tkachuk, 2016).

Central vertical sacred pole simzi handles seven ancestral spirits' heads and tops with a Minley bird figure in the house of a Shaman. Many shamanistic rituals such as herb smudging involve the use of fire and simzi and are performed daily as well as on special

occasions. The house is maintained solely by women, construction and deconstruction of the chum, combustible moss, bushes and firewood preparation, smudging is dependent on her. She can freely walk and touch everything in the house including sacred pole and maintain fire and men believe in her spiritual mighty power to give and take human life, to empower and disengage sacred meaning of the simzi pole. Man and women are understood as opposing elements that converge in the center, man's place in chum (si-nyangi) is further from the entrance when woman's (nie-nyangi) is closer. Geometrical spatial allocation goes along with the sacred meaning behind it. Thus, women's space, protector from the evil, adjoins to the entrance doors and the opposing is considered as men's. Moreover, it is a serene sacred space (si) where all everyday utensils and the casket with spiritual patrons' figures are kept. (Golovnev, 1995).

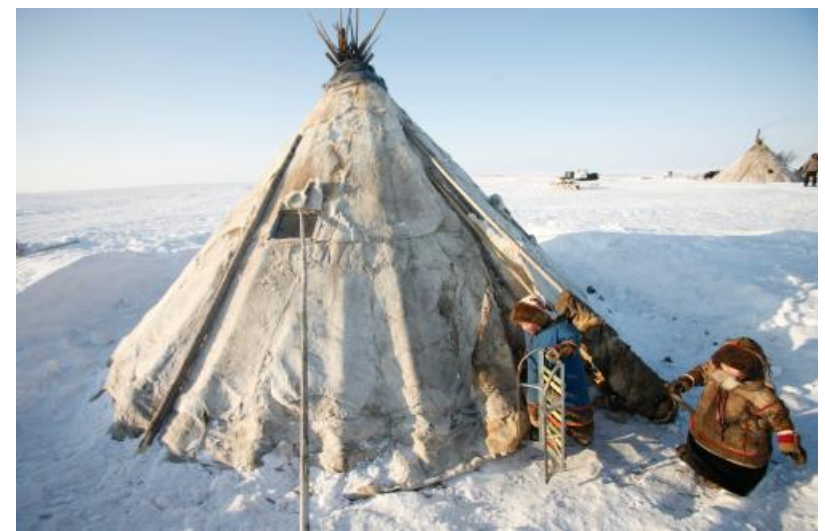

Figure 4. Chum in winter (Kristen Richard, 2016).

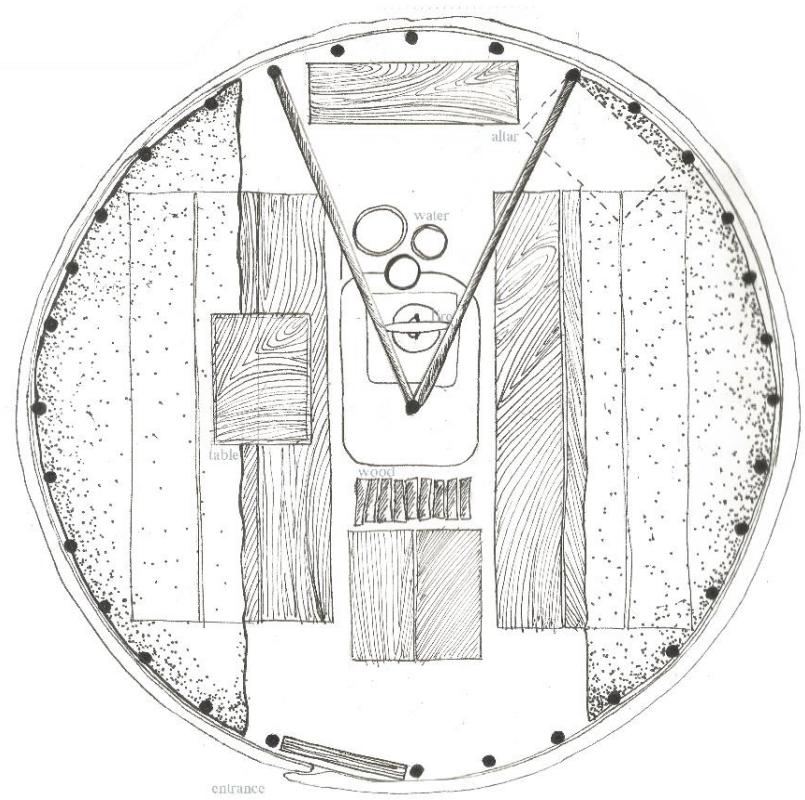

Figure 5. Interior plan of the Chum (Developed by Author). 


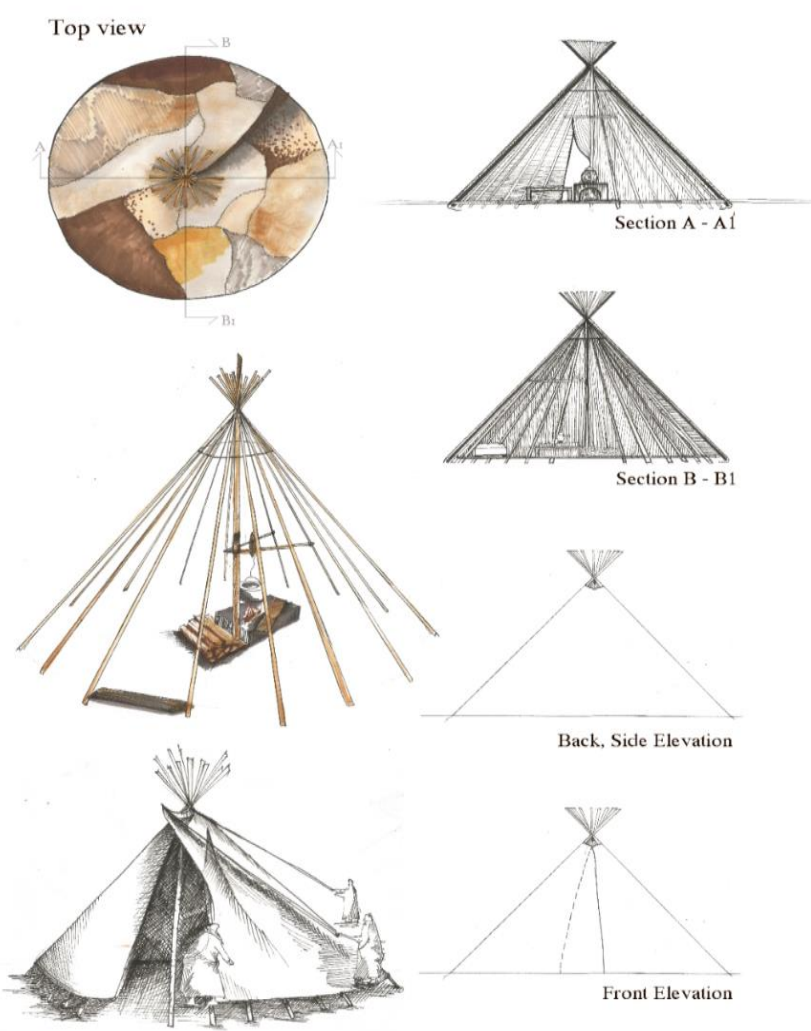

Figure 6. Elevations and sectional views; Chum illustrated during the construction process (Developed by Author).

Vernacular architecture is the result of peoples' adaptation, reflector of their culture, believes and traditions. Maximum affordable or free local sustainable materials and inherited techniques are used in the construction of these dwellings. Speaking about Nenets people's vernacular architecture, Chum is the only tangible object to absorb, conserve and afterwards reflect traditions and mindset of Samoyeds - Siberia inhabitants and nomadic nations in general. Their life is a rare example to bear authenticity in the modern globalized world. Moreover, thence providing pure cultural architectural evidence.

3. Tent-like architectural form links distant continents' cultures.

Chums as well as Native American Tipis, dwellings more than 6000 kilometers away, have striking similarities despite the distance. One can notice the connection between distant cultures of Siberian and America's first inhabitants through their vernacular architectural heritage. When studied more in detail and through the prism of equally important spheres of linguistics and genetics, too, it can serve as an evidence of cultures' connection.

The motivation and the leading force for most vernacular cultures remains to be the spiritual aspect of lives and thus every details of the indigenous dwelling becomes more than just a form but a conveyor of traces in some cases and the preserver of the heritage in others. Regarding architectural similarities, Siberian chum and Native American tipi are of circular shape, with fire as a main central element and shared spiritual background. Indigenous dwellings are both using poles to shape a cone structure and are covered with canvas or animal skins.

This segment of the study will present SiberianNative American connectivity analysis alongside the synthesis of different perspectives to enrich their hypothetical relativity to one another from an architectural standpoint.

\subsection{Dene-Yeniseian, a linguistic link between America and Siberia.}

Due to the vital present-day debate apropos the origin of Native Americans, this paper suggests an alternative look upon their heritage comparison which is involving architecture. Some researchers are stating they have moved from West-Asia, and contemporary ones believe the wave of migration came from Siberia via north-eastern Alaskan bridge. A linguistic approach to this discussion, a hypothesis of Na-Dene (excluding Haida) and Yeniseian languages' connection was presented in Dene-Yeniseic Symposium held in Alaska in February, 2008 (Vajda, 2010). It included multiple notable linguistic researches and was reinforced by various more from spheres of archaeology, genetics and folklore. Na-Dene is one of the most studied and widely used indigenous languages of Americas. Yeniseian, however, is a vestigial linguistic family with only Ket remaining in scarce use. Nonetheless, I would propose this hypothesis to be applied on the Indigenous American and Central Siberian cultures' relationship. Siberian communities and nations can be differentiated into several groups when conducting linguistic, genetic, folklore and religious analysis. Thus, we can easily notice similarities in Samoyeds' or Nenets' and Kets' shared traditions, spiritual life background, worshiping animism, and vernacular dwellings projecting as a preeminent cultures' preservation object.

\subsection{DNA analysis that unveil Native American ancestors.}

Another biological perspective was recently proposed by the international group of researchers. Despite the fact that that the accurate ancestor of Native Americans remains uncertain, the analysis led by the 
Centre for GeoGenetics, Natural History Museum of Denmark (University of Copenhagen) links them with Siberian indigenous population. The group of scientists sampled a 24,000-year-old skeletal remain from the Upper Paleolithic site of Mal'ta in southcentral Siberia at the Hermitage Museum (Saint Petersburg) in 2009; and the second sample from Afontova Gora-2 that is dating to about 17,000 years ago. Results revealed the direct connection to Siberia. The group of scientists led by Eske Willerslev "estimate that 14 to $38 \%$ of Native American ancestry may originate through gene flow from this ancient population" (Rasmussen, S., et al., 2014, 87). Both of these hypotheses remain debatable, however outcomes demonstrate how vernacular architecture in its original form can act as a culture bridge.

\section{Indo-Aryan Settlement of Arkaim - Coexistence of Sacred and Material.}

Arkaim is less studied and distant in time vernacular settlement that is embodying spiritual aspect of human life. It also became an architectural evidence to convey hereditary messages. Fire-centered space organization is referring to the fire-worshiping Indo-Aryan nature of the settlement with no doubt, creating a universal network of local architectural systems.

The ancient settlement is located in Trans-Ural Steppe, southern part of Chelyabinsk region of Russia. Arkaim and Petrovka (settlements) are rare examples of Sintashta vernacular architecture which existed in the $2^{\text {nd }}$ century $B C$ and is known for extensive copper and bronze metallurgy as well as for astronomically verified settlements' layouts. Some sources are dating it back to $8^{\text {th }}-9^{\text {th }}$ century BC (Khafizov, 2009).

It was a birthplace of numerous cultures where Indo-Aryans, Turks and Ugors coexisted in their beginnings. Arkaim's discovery is verily underappreciated in relation to other world renowned historical sites (Zdanovich, 2004). The area remains poorly studied and even the exact date of its origin is still unknown. In the traditional system of chronology sites date back to XVIII-XVI centuries BC, at the same time radiocarbon analysis indicates the XXI-XVIII centuries BC. Moreover, in the past it was in the risk of deterioration. In 1987 archaeological expedition of Chelyabinsk State University, Ural branch of Russian Academy of Science, discovered more than 70 archaeological sites in the 21 square kilometers area of oval shaped Bolchekaraganskaya Valley, framed by the
Ural Mountains. Findings are from various eras: temporary towns from Middle and New Stone Ages - Mesolithic and Neolithic to mounds and ritual fencings of Kimak and Kipchak tribes. However even with the obvious historical value, the area was meant to be flooded and serve as a water reservoir if not the will and efforts of Gennady Zdanovich that proofed the significance of the area and it was declared cultural reservation in 1991.

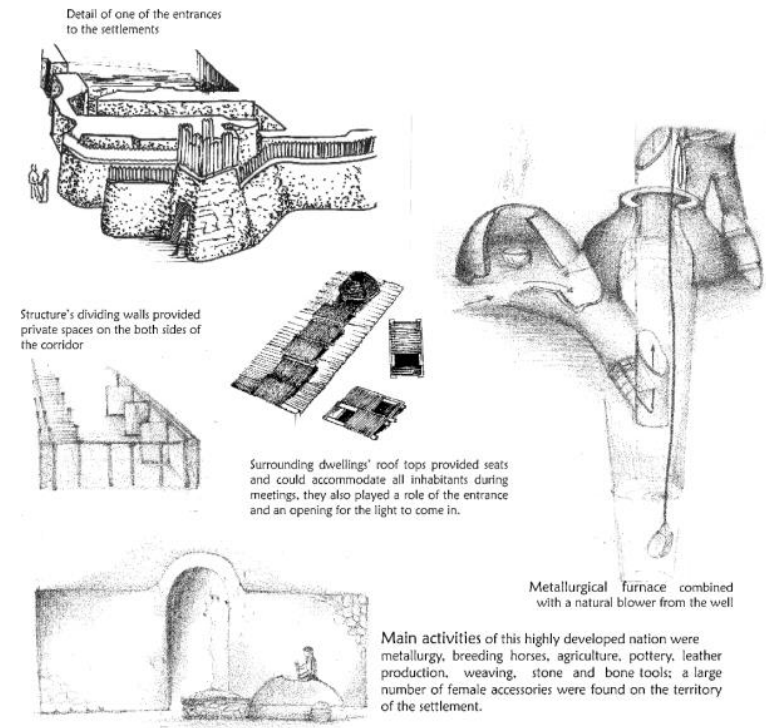

Figure 7. Illustrative details of the indigenous habitat (Developed by Author).

The deeper research of more settlements and cemeteries that refer to the same culture occurred in the late 1980s after the decipherment of aerial images by Batanina and Levite that indicated mounds' forms. Arkaim is an evidence in the architectural tangible form that shows the high development level of so-called "cities of the country", southern part of Chelyabinsk region of Russia that includes the settlement, numerous ancient mounds, necropolises and other archaeological finding. As seen on the case studies of all vernacular architecture examples presented in this research, this settlement unveils consciously planned space organization that bears idem centralized sacred relation to fire in a different scale. 


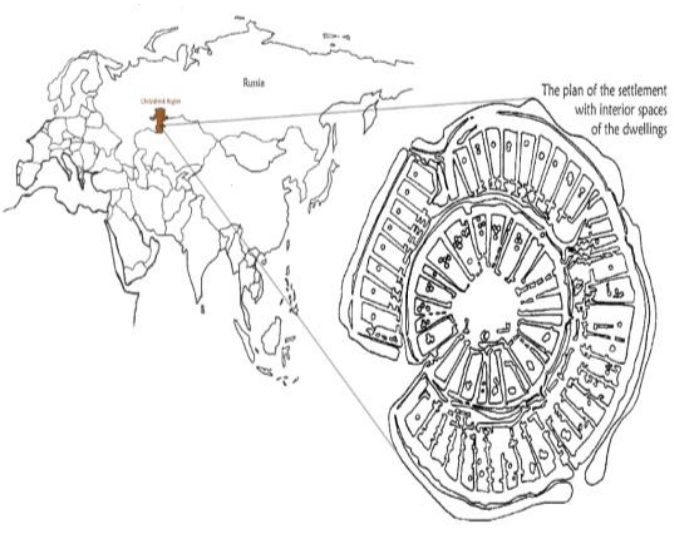

Figure 8. Location and the plan of the settlement with interior spaces of the dwellings (Developed by Author).

The circular settlement is 150 meters in diameter and covers 20,000 square meters area. Located on the confluence of two rivers in the elongated valley, surrounded by hills and ridges, its geometry objectifies the astronomical concept in its form. Houses follow the round shape forming two inner circles outlined by a moat and a wall. Plan's central rectangular square was used for sacral religious acts. Surrounding dwellings' roof tops provided seats and could accommodate all inhabitants during meetings and rituals. "Evidently, the fire ritual played a major role here, considering that Zoroastrianism, the solar religion of fireworshipers, arose in these places." (Khafizov, 2009, p. 40).

66 trapezoidal shape dwellings were revealed inside the settlement using geophysical methods and archaeological excavations, and 20 of them underwent detailed analysis. The size of single residential building varied from width 110 to 180 square meters, 8.6 meters in width and 20 meters in length (Zdanovich et.al, 2009). Zdanovich also noted that two outer rings of fortifications were adapted for astronomical observations. Following ones were two dwelling circles and one street with sewerage. The second defensive wall consisted of a log-ground parts and wooden parapet and bypassed by a 2 meters deep moat. Fortifications were simultaneously main walls of the settlement; two neighboring sectors were divided by a wall in between. One Arkaim's sector - could hold up to 40 - 60 people. Different family clans occupied private bedrooms separated by wooden partitions which were warmed up with the central oven the hearth of the house. Typical dwellings had only two exits - one terrestrial, the other, from the opposite end, led by the stairs to the roof opening which let the light to come through. There were different areas in the house: almost all dwellings started with a small courtyard, with the stove in the corner and the pit connected with the storm sewerage. Then the corridor began with small rooms on both sides (Zdanovich, 2004).

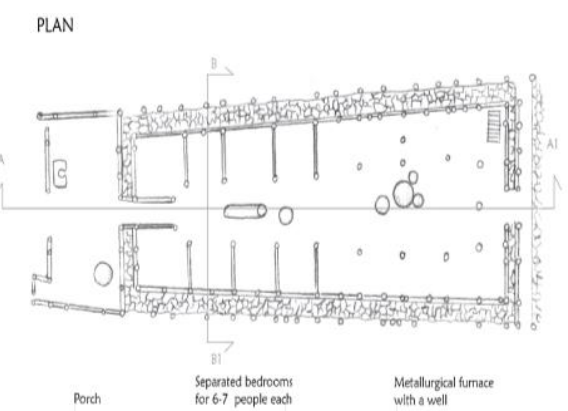

Figure 9. Plan of one single dwelling (Developed by Author).
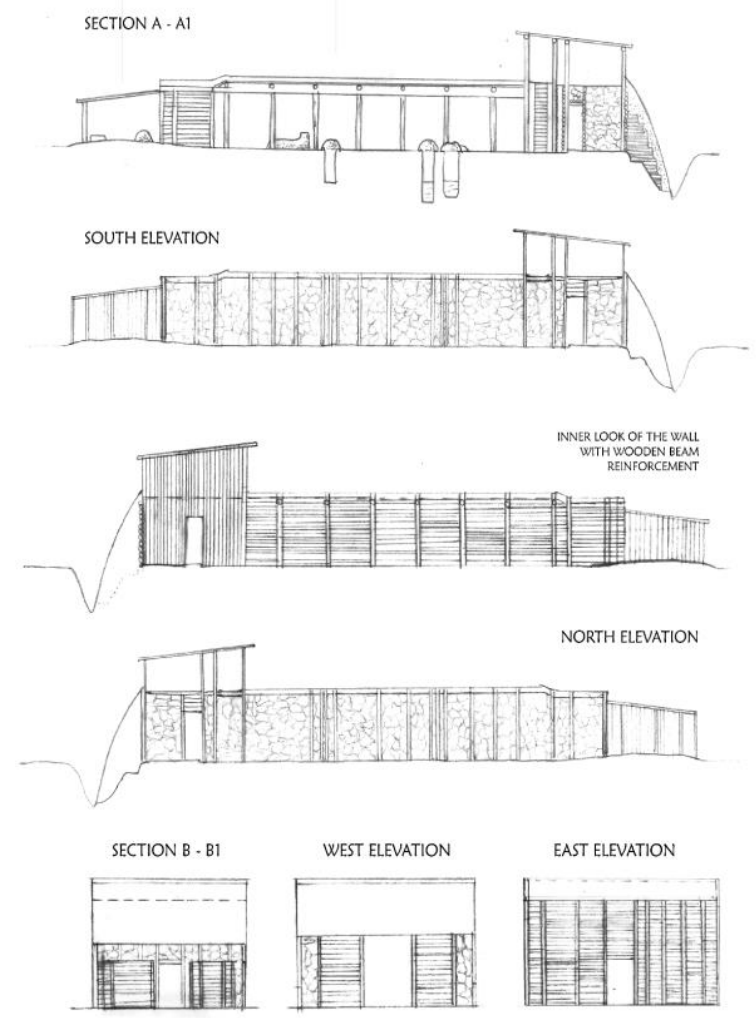

Figure 10. Elevations and Sections on Arkaim dwelling (Developed by Author).

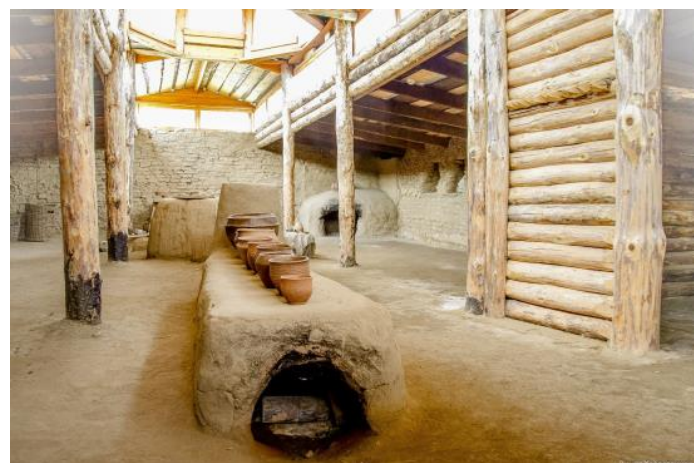

Figure 11. Reconstruction of the dwelling in Arkaim Museum. (Rinat Hayratdinov). 
Working area and general family gathering place occupied approximately one-third of the house. Architectural, domestic and handcrafted findings are pointing on the fact that metallurgy was inhabitance's primary occupation along with leather, pottery stone and bone tools production, weaving, breeding horses and agriculture. There was a well-fridge (pit, cellar), metallurgical furnace combined with a natural blower for the well and stoves in every house. An altar with skulls and other bones of domestic animals was placed at the bottom of each fireplace.

House represented harmonized unity of earth, fire, air and water. Indoor comfort was achieved with both cold and hot spaces, potable and household water accessibility for everyday and ritual ceremonial needs. Dwelling accommodated spaces for sleeping, recreation, work and prayers. Each sector replicated the principles of the settlement structure, thus fireplace can be identified as the gathering space for a family or a community, in the scale of a single house or the settlement respectively. The whole city was concentrated around the central square, the heart of Sacred Arkaim. (Zdanovich, et.al, 2009). Arkaim settlement communicates the system of men and nature symbiosis in unified arrangement of various elements, forms and structures. One can state that vernacular architectural representatives of Sintashta culture point on very developed nations' habitual and scientific level.

Spatial arrangement of Sintashta nation is referring to the one of Chums and Tipis. Centralization of fire is noticed in Arkaim in the dual form. Being the early origin of Zoroastrism, the settlement combined fire worshiping with animism. This element appears to intersect distant detached or relative cultures' vernacular dwelling spatial arrangements.

\section{Japanese vernacular architecture and interior spatial arrangement.}

\subsection{Anthropological approach to the Japanese vernacular architectural differentiation.}

Due to Japanese land' isolation, long standing attentiveness and care to national heritage, vernacular architecture was preserved and is treated with respect till today. Professor Jean Louis Armand de Quatrefages differentiated anthropologically juxtaposed races into four groups: (1) Almost entirely blended 'Negrito type', (2) 'Yellow element' with the well recognizable Chinese origin, (3) 'White Ainu element' and (4) 'White Indonesian element'. $\mathrm{He}$ noted that "yellow and white elements occasionally occur juxtaposed and not intermixed in any striking manner." (Mechnikov, 1881)

Bearing the same approach in mind, development of Japan may be differentiated into two periods, Pre-Buddhist and later mainland-influenced. The earlier one includes Jomon (10000 BCE-300 CE), Yayoi (300 BCE-300 CE) and partially Tomb Mound (300-710) periods. Flat-land buildings, heichi jukyo came from an earlier pre-ceramic period and can be of a circular or rectangular plan and be constructed using vertical and horizontal intertwined poles. Following Yayoi and Tomb Mound periods experienced Korean blending that influenced all spheres of life including architecture primarily with the expand of wet rice agriculture (Young M., Young D. T., 2012). Dwellings could be grounded, flat or raised on poles. Details such are the interior spatial arrangement of Pre-Buddhist architecture examples remain obscure, however, clearly identified forms and construction methods retained their influence by this time.

\subsection{Ainu huts, Indigenous Japanese dwellings.}

Ainu people may be considered the aboriginal nation of Japanese archipelago. As recorded by the number of researchers and travelers ( $\mathrm{J}$. Batchelor, I. L. Bird, J. K. Goodrich) in the late 19th century, Ainu's huts are of a flat land construction with very minimal furnishing and the central elongated hearth. Similarly as in the previously discussed chum interior organization, Ainu's dwellings' hearth-sacred relationship follows the same algorithm in terms of physical and intangible. This fact is very surprising, however one can easily notice on plans (image 12-13) how repetitive is the sequence of entrance, fire (hearth) and the sacred. Goodrich wrote: "A sacred window is left in the middle of the eastern wall, through which the sun-god is worshiped, and before this an inao is placed. ...the northern of the fireplace is sacred to the family" (1888, p.499). So-called 'Inao', willow-shavings as the representations of gods occupy the essential part of the dwelling (Batchelor, 1892). Thus, following the same analogy, sacred parts of the dwelling are centralized hearth (place of fire) and further inner space, east window with 'inao'. 


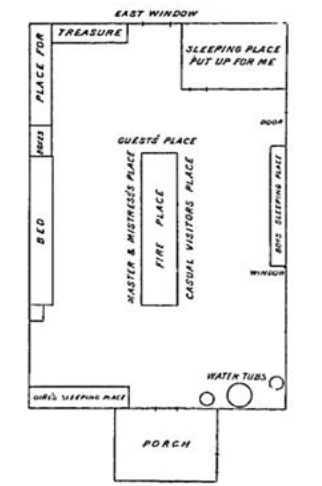

Figure 12. Plan of an Ainu Hut (From Batchelor, 1892, p.73)

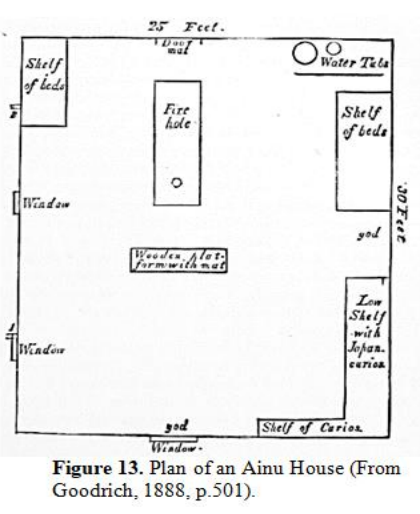

\subsection{Cha-no-yu, spiritual meaning in spatial organization of Japanese tearooms.}

Cha-no-yu may be considered one of those traditional Japanese typologies that are prevalent in the modern life. Not always consciously taken into account, the background that stands behind habitual actions and planned spaces goes far back to Japanese spiritual origins.

Among eight varieties of tearooms' arrangements most common and original one is the 'four-and-a-half' mat where the middle 'ro' mat and a hearth are surrounded by four full tatami mats (Sadler, 2011 ).

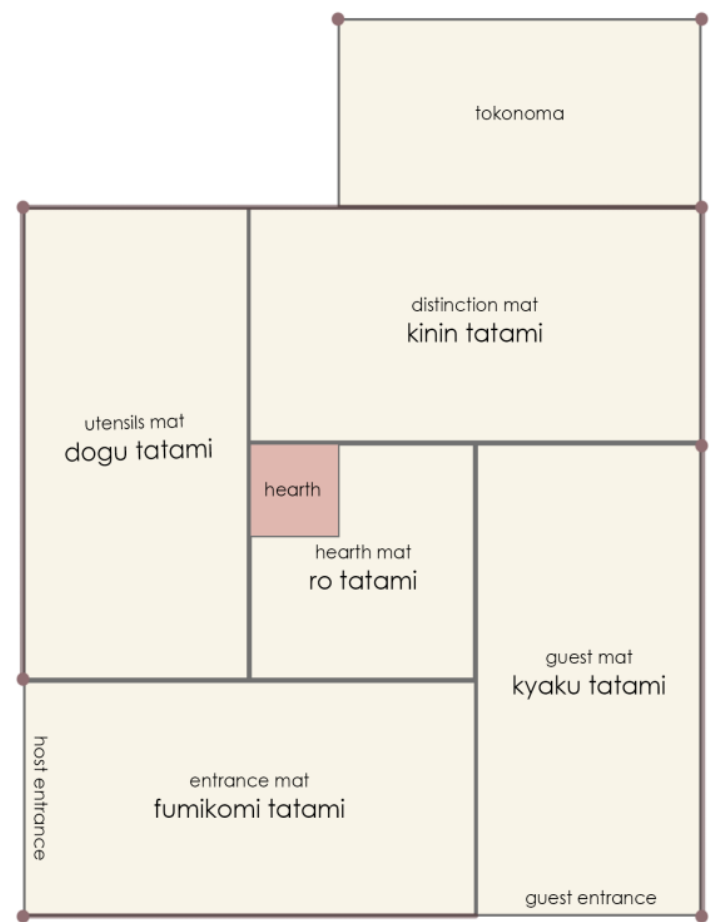

Figure 14. Four-and-a-half Tatami Tearoom arrangement (Developed by Author).

Centralized hearth algorithm, transferred to the common dwellings' plans found its place and meaning in the regular routine. "The Japanese hearth is also normally in the dirt-floor kitchen, but in the middle of it, or sometimes at the center of tatami room" (Sirvimaki, 2003, p.86). Black (2011) also presents how a typology of a tearoom with centralized hearth repeats in various building types, including so-called 'thatched minka' farmhouse or people's house and in some samurai residences. Moreover, the central tea table, commonly seen in later (Edo period) occurred typology, the 'machiya' (city house), can be considered as an evolved adaptation of the hearth (Black, 2011). However, "Despite its centrality to Japanese cultural identity, Japanese Tea ritual or chanoyu has been treated superficially in the ethnographic literature" (Anderson, 1987, p. 475). Anderson studies The Way of Tea and the religious symbolism of its etiquette that unconsciously rebounds in daily tea ceremonies. He noted the strong presence of Shinto and Taoist believes in actions (1987). The final stage of the ceremony finds its place in the tea room of chashitsu (tea house).

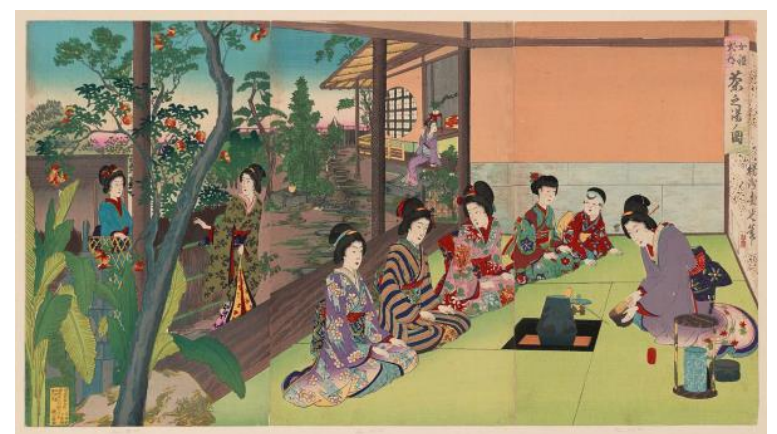

Figure 15. Tea Ceremony, from the series Etiquette for Ladies (女礼式ノ内 茶之湯ノ図) (Yôshû Chikanobu, 1888)

And even the traditional house of modern times retains this important feature in its approximate form and meaning. Irori (sunken hearth) is named to be the focus of household life, place for communication and relaxation and to preserve hierarchal order of guests' seating placement.

\section{Conclusion.}

Recalling three principles of conservation, in the current context of vernacular heritage, introduced by Hosey, which include: 'reduce, reuse, recycle', the fourth step comes as first, 'rethink' (2012). Following my considerations, modern strategy of vernacular architectural heritage should be rethought to be further improved. This paper aimed to find the unifying algorithm through several distant or relative indigenous dwellings' analysis. Detailed case study included Chums of Nenets from the Central Siberia, Tipis of indigenous Americans, 
Arkaim Settlement of the early Indo-Aryans, Ainu aboriginal dwellings and the Cha-no-yu traditional Japanese teahouse. Successfully, the proposed algorithm was noticed to be repetitive in all of those examples. In this regard, the unifying centralized fire spatial arrangement is also bearing same spiritual significance in its background. Thus, vernacular architecture in the modern universalized world could be introduced in new glocal, simultaneously global and local, perspective.

\section{Acknowledgments}

This research did not receive any specific grant from funding agencies in the public, commercial, or non-for-profit sectors.

\section{References}

Kozhanovskiy A. (N.), Makarevich V. (M.), Popov V. (A.), Puchkov P.(I.), Sytnyansky G.(Y.). (1998) Big Russian Enthyclopedy. (928) Moscow: Prosveshenie . Adopted from http://www.greatbook.ru/

Monachova Z. (V.), (2002). Urokit inin, Life of the nomad encampment. Krasnoyarsk: Publishing house Sybirskiy Promisel. Adopted from http://osiktakan.ru/ethnos/chum0.html

Pikunova Z. (N.), (1999) Ilustrated Vocabulary of Evenks Language. (191) Saint Petersburg: Publishing house Prosveshenie. Adopted from https://www.twirpx.com/file/1602501/

Boyarsky P. (V.), Stolyarov V. (P.). (2000) Arctic exploration history. Island Vaigach. Natural and cultural heritage-1. Moscow: Russian Research Institute of Cultural and Natural Heritage. Adopted from http://heritageinstitute.ru/library/publications/item/3281-ostrovvajgach-kulturnoe-i-prirodnoe-naslediepamyatniki-istorii-osvoeniya-arktiki-kniga-1-mrossijskii-nii-kulturnogo-i-prirodnogo-naslediyaimeni-d-s-likhacheva-fond-polyarnykhissledovanij-2000-372-s-il

Pika A., Chance N. (A.). (1993) The Nenets and Khanty of the Russian Federation, in State of the Peoples: A Global Human Rights Report on Societies in Danger. Boston: Beacon Press. Adopted from http://arcticcircle.uconn.edu/HistoryCulture/Russ ia/nenets.html

Chance N. (A.), Andreeva E. (N.). (1995) Sustainability, equity, and natural resource development in Northwest Siberia and Arctic. Human Ecology, No.23, 217-240. DOI https://doi.org/10.1007/BF01191650

Anderson D. (G.). (2006) Dwellings, Storage and Summer Site Structure among Siberian Orochen Evenkis: Hunter-Gatherer Vernacular Architecture under Post-Socialist Conditions. Norwegian Archaeological Review, Vol. 39, No. 1. 2-5. DOI 10.1080/00293650600703894
Lissner I. (1961) Man, God and Magic. New York: G. P. Putnam's Sons. Adopted from https://books.google.com.cy/books/about/Man _God_and_Magic.html? id=yE80k4rB_7EC\&redir_ esc=y

Shirokogoroff S. M. (1929) Social organization of the Northern Tungus. Shanghai: The Commercial Press. https://doi.org/10.1017/S0035869X00112171

Vajda J. E. (2013) Vestigial possessive morphology in Na-Dene and Yeniseian. Working Papers in Athabaskan (Dene) Languages 2012. Alaska Native Language Center Working Papers, No. 11 , eds. Sharon Hargus, Edward Vajda, Daniel Hieber. Fairbanks, AK: ANLC.3. Adopted from https://www.uaf.edu/files/anlc/Vajda 2013 Vesti gial.pdf

Vajda, E. (2010). "Siberian Link to Na-Dene languages." The Dene-Yeniseian Connection, ed. by J. Kari and B. Potter, 33-99. (Anthropological Papers of the University of Alaska, new series, vol. 5.) Fairbanks: University of Alaska Fairbanks Department of Anthropology. Adopted from https://www.uaf.edu/anlc/dy/dy2008/

Dunn M., Anthropological papers of the University of Alaska: The Dene-Yeniseian connection. Ed. by James Kari and Ben A. Potter. Fairbanks: University of Alaska Fairbanks, (2010). Pp. vi, 363. DOI: 10.1353/lan.2012.0036

Rasmussen, S., Stafford J. T., Orlando L. A. A., Metspalu, E., Karmin, M., Tambets, K., Rootsi, S., Mägi, R., Campos, P., Balanovska, E., Balanovsky, O., Khusnutdinova, E., Litvinov, S., Osipova, L. M., Fedorova, S. A., Voevoda, M.I., Degiorgio, M., Sicheritz-Pontén, T., Brunak, S., Demeshchenko, S., Kivisild, T., Villems, R., Nielsen, R., Jakobsson, M., Willerslev, E.. (2014) Upper Palaeolithic Siberian genome reveals dual ancestry of Native Americans. Nature, Vol. 505, No. 7481, 2014, p. 87-91. DOI: 10.1038/nature12736

Mchedlov M. P., Averyanov U.I., Basilov V.N., (2002) Религии народов современной России: САоварь, 2 (Religiy narodov sovremennoi Rossii: Slovar, 2) Moscow: Respublika.

ISBN 5-250-01818-1. Adopted from https://www.twirpx.com/file/1348996/

Prohorov A. M. (1978) Большая советская энциклопедия [Bolshaya Sovetskaya Enziklopedya] (Vol. 29, 3). Moscow: Sovetskaya Enziklopedya. ISBN: 9785852703206 / 9785852703668. Adopted from http://www.encyclopedia.ru/cat/books/book/4 9464/

Golovnev A. V. (1995) Говорящие Культурыю Традиции Самодийцев и Угров. [Talking Cultures. Samoyed and Ugrian Traditions] Govoryashiye Kulturi. Traditsii samodiytsev i ugrov Ekaterinburg: Ural Branch, Russian Academy of Sciences. Adopted from http://ethnobs.ru/file/Golovnev_Govorjashhie_ku Itury.pdf 
Zdanovichh G. B., Zdanovich D. G., Kislenko A. M., Kupriyanova E. V., Petrov F. N. (2009) (78-80, 94) Arkaim: at the origins of civilization. Chelyabinsk: Arkaim. Adopted from http://www.arkaimcenter.ru/science/nashi-publikacii/

Zdanovich G. B., Batanina I. (M.), (1995) "Cities of the country" - fortified settlement of the Bronze Age in the XVIII-XVI century. BC. in the Southern Ural; Arkaim. Research. Discoveries. Chelyabinsk: Arkaim. Adopted from http://www.arkaimcenter.ru/science/nashi-publikacii/

Kislenko A. M., (2004) What is Arkaim? Arkaim Through the pages of the ancient history of the Southern Ural, (11-20) Chelyabinsk: Crocus. Adopted from http://www.arkaimcenter.ru/science/nashi-publikacii/

Zdanovichh G.B., (2004) Arkaim and the "Country of towns": dialogue of cultures. Arkaim - Through the pages of the ancient history of the Southern Ural, (35-47) Chelyabinsk: Crocus. Adopted from http://www.arkaim-center.ru/science/nashipublikacii/

A. R., (2009) Ancient History of Humankind in the light of modern scientific discoveries. (1) (39-41) Kazan: Dom Pechaty. Adopted from https://www.ozon.ru/context/detail/id/13933527 3/

Black A., (2011) The Japanese House: Architecture and Interiors. North Clarendon, VT: Tuttle Publishing. $\quad$ ISBN: 9784805312094.

https://www.tuttlepublishing.com/books-bycountry/the-japanese-house-paperback-withflaps

Young D. T., Young M., Yew T. H., Simmons B., Murata N. (2012) Art to Japanese Architecture. Tokyo: Tuttle Publishing. ISBN: 9784805313022. Adopted from https://www.tuttlepublishing.com/books-bycountry/the-art-of-japanese-architecturepaperback-with-flaps

Young M., Young D. T. (2012) Introduction to Japanese Architecture. Tokyo: Tuttle Publishing Adopted from

https://www.amazon.com/IntroductionJapanese-Architecture-PeriplusAsian/dp/0794601006/ref=sr_1_3?s=books\&ie=UTF 8\&aid $=1544630390 \& s r=1-3$

Ronald R., Alexy A. (2017) Home and Family in Japan: Continuity and Transformation (Japan Anthropology Workshop Series). Abingdon-onThames: Routledge Adopted from https://www.routledge.com/Home-and-Familyin-Japan-Continuity-and-Transformation/RonaldAlexy/p/book/9780415488679

Sirvimaki M. (2003) Layouts and Layers: Spatial Arrangements in Japan and Korea. Seoul: Sungkyun Journal of East Asian Studies, 3(2), pp. 80-108.

Adopted

from

https://docplayer.net/20941722-Layouts-and-

layers-spatial-arrangements-in-japan-and-

korea.html
Jennifer L. A., (1987) Japanese Tea Ritual: Religion in Practice. Man, New Series, 22(3), London: Royal Anthropological Institute of Great Britain and Ireland. pp. 475-498. Adopted from http://www.sjsu.edu/people/jennifer.anderson/d ocs/Tea_Ritual_Dynamic_Mythology_and_Nation al\%20ldentity.pdf

Sadler A. L. (2011) Cha-No-Yu: The Japanese Tea Ceremony. Tokyo: Tuttle Publishing. ISBN: 0804834075. Adopted from https://books.google.com/books?id=WrnWAgAA QBAJ\&printsec $=$ frontcover $\# \mathrm{v}=$ onepage\& $q \& f=f a l$ $\underline{\text { se }}$

Mechnikov L. I. (1881) in Stevenson R. K. (Ed.), Concerning Japanese Origins. Anthropology Society of Paris, Meeting of November 3, 1881. Paris: Anthropology Society of Paris. Adopted from

https://archive.org/details/ConcerningJapanese Origins_215

Batchelor J. (1892) The Ainu of Japan. The religion, superstitions, and general history of the hairy aboriginals of Japan. London: The Religious Tract Society. Adopted from https://archive.org/details/ainuofjapanrelig00ba tcuoft/page/n5

Goodrich J. K. (1888) Ainu Houses and their furnishing. In W. J Youmans (Ed.), The Popular science monthly (33). (pp. 497-508) New York: Popular Science Pub. Co. Adopted from https://archive.org/details/popularsciencemon3 3newy/page/498

Bird I. L. (1880) Unbeaten Tracks in Japan: An Account of Travels in the Interior, Including Visits to the Aborigines of Yezo and the Shrine of Nikko. London: John Murray. Adopted from https://doi.org/10.1017/CBO9780511709845

Hosey L. (2012) The shape of green: aesthetics, ecology, and design (2). Washington, DC: Island Press. ISBN-13: 978-1610910323.

Adopted from https://books.google.com./books/about/The_Sh ape of Green.html 